\title{
Education of Future Green Engineers for Achieving Sustainable Development in Green Manufacturing Industry
}

\author{
https://doi.org/10.3991/ijep.v11i5.22165
}

\author{
Vladimir A. Kirik ${ }^{1}$, Shanyi Cheng ${ }^{1}$, Natalia I. Vyunova ${ }^{2}$, Olga V. Galustyan ${ }^{1}{ }^{(凶)}$, \\ Saida S. Gamisonija ${ }^{1}$, Sofia D. Galustyan ${ }^{1}$ \\ ${ }^{1}$ Southern Federal University, Rostov-on-Don, Russia \\ ${ }^{2}$ Voronezh State University, Voronezh, Russia \\ olga.galustyan@gmail.com
}

\begin{abstract}
The article is devoted to education of future green engineers for achieving sustainable development in green manufacturing industry. It outlines that green engineering is an important industry which aim is to reduce consumption, to save resources, and to achieve sustainable development in manufacturing. Green manufacturing puts forward new requirements for the training future green engineers. The article reveals the principles of educating future green engineers. Specifical attention is paid to the improvement of the teaching system training of future green engineers, strengthening the teaching staff, changing the teaching mode, strengthening teaching practice and practical training for achieving teaching goals. The authors conclude that it is necessary to clarify the goals of training of future green engineers, and to establish reform the teaching content of green engineering course.
\end{abstract}

Keywords - students, future green engineers, education, sustainable development, green manufacturing

\section{Introduction}

The concept of sustainable development is a hot research topic in various countries in the world today. Due to the fact that many industrialized countries have undergone industrial upgrading and transformation, it has become a consensus to embody the concept of sustainable development in the manufacturing sector $[1,6,12]$. There are many ways and measures for achieving it. The focus is development of green manufacturing among them. The specific measures are inseparable from preparing of a team of high-quality professionals $[7,8,18]$. Therefore, it is necessary to explore the issues of educating future green engineers for adapting to the sustainable development.

Green engineering professionals refer to professionals who have a expertise and specialize in green manufacturing. Sustainable development as a clear concept appeared in the Report of the World Commission on Environment and Development in 1987 [20]. Since that time, this concept was put forward, definition has not been formed 
as a completely unified concept. But most of the documents emphasize that sustainable development is coordination and harmony of nature, society, and economy under conditions of equal importance. Sustainable development of green manufacturing is a concept of harmonious coexistence and order development of society, population and other aspects in the production and manufacturing processes [3, 16, 21].

Sustainable development of green manufacturing and of the entire society are interdependent. So, the main way in achieving sustainable development for green manufacturing is to reflect sustainability of coordination and development in all aspects. At present, the aim is to progress green manufacturing vigorously. Green engineering is based on the original manufacturing model, which is guided by the " $3 \mathrm{Rs"}$ principle (Reduction, Reuse and Recycling), and comprehensive consideration of resource utilization efficiency and environmental impact. Modern manufacturing mode includes green production activities in the production system and remanufacturing activities in the recycling system, and its goal is to achieve coordination and optimization of enterprise economic, social, and environmental benefits [15, 17, 23].

\section{Background}

The shift from traditional manufacturing to green manufacturing involves a brandnew employment and education model. Many jobs are changing because of transformation and upgrading of enterprises during the past few years, that results in a shortage of professionals in green manufacturing. Therefore, it is necessary to provide high quality education of future green engineers.

Development of green manufacturing, transformation and upgrading of industrial structure, improvement of quality and efficiency, transformation from a large manufacturing country to a strong manufacturing country put forward new requirements for training future green engineers. However, education of future green engineers faces many challenges, and it cannot meet the requirements of manufacturing transformation and upgrading effectively $[2,5,11]$.

Green manufacturing means energy saving, emission reduction and sustainable development. Education of future green engineers should be an all-round process, it should run through the entire process of production considering the inseparable relationship between manufacturing, resources, and environment. Taking China as an example, green manufacturing is in its infancy in many regions nowadays and understanding of its connotation needs to be further improved [4, 9]. Firstly, there are problems in cultivation of green manufacturing, which cannot consider the impact on the environment only and ignore two major aspects of manufacturing process and resources. Secondly, it is necessary to clarify the training objectives to facilitate the teaching and training of future green engineers $[10,14,26]$.

The existing university courses for future green engineers cover professional knowledge system according to the requirements of curriculum standards. According to $[2,13,24]$ education of future green engineers should be based on the following requirements: 
1. Curriculum system should be extremely practical. Introduction to the theoretical course of green engineering in system can only teach green knowledge, and the lack of practical links in green manufacturing has certain limitations.

2. Green engineering course itself should be standardized to facilitate assessment, especially for engineering students, which can be used as an assessment indicator.

3. The level of teaching needs to be improved from the perspective of the academic structure. Faculty should involve industrial partners of green manufacturing into the teaching staff.

These problems must be resolved through acquired learning and training.

\section{$3 \quad$ Materials and methods}

\subsection{Participants}

We conducted experimental work on realization of education of future green engineers in 2020. Students at Southern Federal University, Rostov-on-Don participated in the study. The total number of students was 211 (107 participants were in experimental group, control group included 104 participants). Age range of the students was from 19 to 21 years.

\subsection{Principles of education}

Education of future green engineers should be based on the following principles:

1. It is necessary to clarify the training goals of green engineering course and to establish a framework for green engineering course throughout the entire process of manufacturing, resources and environment, and product use.

2. It is necessary to establish a framework for green engineering course according to industry characteristics and local economic needs. The training framework should include obtaining knowledge and skills in green manufacturing, green behavior, green attitude, and green values. It should be based on strengthening the teaching practice and internship training.

3. It is necessary to strengthen the concept of green manufacturing, and to understand green manufacturing technology, methods, and feasibility through corporate practice, to implement different green manufacturing technologies for different sections, and to make overall arrangements for energy utilization throughout the enterprise.

4. It is necessary to propose improvement of measures for green manufacturing implementation plans to enterprises through theoretical research, which complements existing technologies [13, 19]. 


\subsection{Program of education of future green engineers}

We realized program of education of future green engineers for improving curriculum system and strengthening the practice of green engineering education which was based on the experience of scientists $[19,22,25]$ and included:

1. Strengthening of the construction of green engineering practice courses to achieve the teaching effect of doing and learning while experiencing, and at the same time enhancing of the social significance of green engineering.

2. Formation of certain range of standardized operations or design procedures in a certain energy-saving technology field to facilitate the assessment of students.

3. Following of the concept of lifelong learning because it goes beyond formal education and training, including "skills" and "development". Life-long learning helps the students to acquire and to integrate various knowledge and skills. University teaching should cultivate students' life-long learning ability to equip them with this quality, which will be more conducive to the sustainable development and progress of green manufacturing.

4. Advancement of teaching level in green engineering to strengthen cooperation with enterprises, to send teachers to go to factories to learn green manufacturing technology regularly, to understand the needs of enterprises. Experts should be invited to universities to carry out training courses, lectures, and other forms of reeducation to improve teachers' green concept and to keep pace with the advanced level.

5. Increasing of teaching content, combining with specific enterprise technical characteristics in order to increase practical teaching content, such as sterilization heat recovery, refrigerant heat exchange, intelligent heat management, simulation system control, etc. It should serve as supplement to the knowledge unit and in-depth integration of bioengineering professional system knowledge using green manufacturing.

6. Reforming of the teaching content is needed so that students can use the knowledge they have learned to design and to demonstrate reasonable process routes, to perform reasonable power and heat exchange calculations and to type selection demonstrations. on equipment, and to perform correct calculations on materials and hydropower balance. Complex knowledge and skills are needed for green engineering projects to solve problems such as high levels of energy consumption, wastewater discharge, and COD emissions.

7. Application of innovative teaching methods based on teaching content, knowledge system settings, construction of relevant cognitive and practical teaching links. Students will deepen their understanding of green manufacturing using virtual laboratories.

\section{Results}

The purpose of the initial stage of the experiment was to determine the initial level of professional competence of future green engineers. Professional competence of 
future green engineers involves three components such as activity, informational, and research one. Activity component includes student's ability and willingness for effective planning activities, seeing problems and goals of the expected result in green engineering, searching ways in achieving goals in green engineering, ability for constant personal growth using personal reserves. Informational component is expressed in student's ability and readiness for searching, analyzing, selecting, and transforming necessary information in green engineering independently, ability for carrying out analytical and synthetic processing of information using traditional and new information technologies. Research component is expressed in student's ability and readiness for acquiring and mastering new knowledge in green engineering independently, putting forward ideas and hypotheses, working with various sources of information, conducting observation, proposing the most rational options for realization of research projects in green engineering.

The practical implementation of education of future green engineers was carried out in the form of an analysis based on Likert scale. The results of the study are presented in Table 1 and Table 2.

Table 1. Level of professional competence of future green engineers in the experimental and control groups at the beginning of the experiment

\begin{tabular}{|l|c|c|c|c|c|c|}
\hline \multirow{2}{*}{\begin{tabular}{c}
\multirow{2}{*}{$\begin{array}{c}\text { Organizational } \\
\text { competence }\end{array}$} \\
\cline { 2 - 7 }
\end{tabular}} & $\begin{array}{c}\text { Low level, } \\
\text { \% }\end{array}$ & $\begin{array}{c}\text { Middle level, } \\
\text { \% }\end{array}$ & $\begin{array}{c}\text { High level, } \\
\%\end{array}$ & $\begin{array}{c}\text { Low level, } \\
\%\end{array}$ & $\begin{array}{c}\text { Middle level, } \\
\%\end{array}$ & $\begin{array}{c}\text { High level, } \\
\%\end{array}$ \\
\hline Activity component & 40.2 & 38.3 & 21.5 & 40.4 & 39.4 & 20.2 \\
\hline $\begin{array}{l}\text { Informational } \\
\text { component }\end{array}$ & 55.1 & 29.0 & 15.9 & 37.5 & 39.4 & 23.1 \\
\hline Research component & 43.0 & 33.6 & 23.4 & 41.3 & 30.7 & 28.0 \\
\hline
\end{tabular}

Table 2. Level of professional competence of future green engineers in the experimental and control groups at the end of the experiment

\begin{tabular}{|l|c|c|c|c|c|c|}
\hline \multirow{2}{*}{$\begin{array}{c}\text { Organizational } \\
\text { competence }\end{array}$} & \multicolumn{3}{|c|}{ Experimental group } & \multicolumn{3}{c|}{ Control group } \\
\cline { 2 - 7 } & $\begin{array}{c}\text { Low level, } \\
\text { \% }\end{array}$ & $\begin{array}{c}\text { Middle level, } \\
\%\end{array}$ & $\begin{array}{c}\text { High level, } \\
\%\end{array}$ & $\begin{array}{c}\text { Low level, } \\
\%\end{array}$ & $\begin{array}{c}\text { Middle level, } \\
\%\end{array}$ & $\begin{array}{c}\text { High level, } \\
\%\end{array}$ \\
\hline Activity component & 12.1 & 37.4 & 50.5 & 41.3 & 38.5 & 20.2 \\
\hline $\begin{array}{l}\text { Informational } \\
\text { component }\end{array}$ & 8.4 & 26.2 & 65.4 & 34.6 & 43.3 & 22.1 \\
\hline Research component & 8.4 & 23.4 & 68.2 & 32.7 & 37.5 & 29.8 \\
\hline
\end{tabular}

The results of experimental work on education of future green engineers in control and experimental groups revealed that in the experimental group the level of professional competence of future green engineers is higher than in the control group, that proves the effectiveness of experimental work. 


\section{Conclusions}

Green manufacturing is an important industry which aim is to reduce consumption, to save resources, and to achieve sustainable development in manufacturing. Training of future green engineers puts forward new requirements to cover professional knowledge system such as practical orientation of curriculum system, facilitating of assessment, involving industrial partners of green manufacturing into the teaching staff. Education of future green engineers should be based on principles which include clarifying the training goals of green engineering course and to establish a framework for green engineering course throughout the entire process of manufacturing, resources and environment, and product use; establishing a framework for green engineering course according to industry characteristics and local economic needs; strengthening the concept of green manufacturing; obtaining of green manufacturing technology, methods, and feasibility through corporate practice; proposing improvement of measures for green manufacturing implementation plans to enterprises through theoretical research.

Specifical attention was paid to the improvement of the teaching system of training of future green engineers. The program of education of future green engineers included such items as strengthening of the construction of green engineering practice courses; advancement of teaching level in green engineering; increasing of the teaching content, combining with specific enterprise technical characteristics; application of innovative teaching methods based on teaching content.

\section{Acknowledgment}

This publication was supported by Southern Federal University.

\section{$7 \quad$ References}

[1] Bonfante, M. C., Raspini, J. P., Fernandes, I. B., Fernandes, S., Campos, L. M. S., \& Alarcon, O. E. (2021). Achieving sustainable development goals in rare earth magnets production: A review on state of the art and SWOT analysis. Renewable and Sustainable Energy Reviews, 137. https://doi.org/10.1016/j.rser.2020.110616

[2] Bosman, L. B., Duval-Couetil, N., Mayer, B., \& McNamara, P. (2019). Using online discussions to develop the entrepreneurial mindset in environmental engineering undergraduates: A case study. International Journal of Engineering Pedagogy, 9(3), 4-19. https://doi.org/10.3991/ijep.v9i3.9491

[3] Calicioglu, Ö., \& Bogdanski, A. (2021). Linking the bioeconomy to the 2030 sustainable development agenda: Can SDG indicators be used to monitor progress towards a sustainable bioeconomy? New Biotechnology, 61, 40-49. https://doi.org/10.1016/j.nbt.2020.10.010

[4] Chen, G., Li, X., Zhang, X., \& Reniers, G. (2021). Developing a talent training model related to chemical process safety based on interdisciplinary education in China. Education for Chemical Engineers, 34, 115-126. https://doi.org/10.1016/j.ece.2020.11.012 
[5] Collins, K. H., \& Jones Roberson, J. (2020). Developing STEM identity and talent in underrepresented students: Lessons learned from four gifted black males in a magnet school program. Gifted Child Today, 43(4), 218-230. https://doi.org/10.1177/1076217520940767

[6] Dantas, T. E. T., de-Souza, E. D., Destro, I. R., Hammes, G., Rodriguez, C. M. T., \& Soares, S. R. (2021). How the combination of circular economy and industry 4.0 can contribute towards achieving the sustainable development goals. Sustainable Production and Consumption, 26, 213-227. https://doi.org/10.1016/j.spc.2020.10.005

[7] Galustyan, O. V., Borovikova, Y. V., Polivaeva, N. P., Kodirov, B. R., \& Zhirkova, G. P. (2019). E-learning within the field of andragogy. International Journal of Emerging Technologies in Learning, 14(9), 148-156. https://doi.org/10.3991/ijet.v14i09.10020

[8] Galustyan, O. V., Solyankin, A. V., Skripkina, A. V., Shchurov, E. A., Semeshkina, T. V., \& Ledeneva, A. V. (2020). Application of blended learning for formation of project competence of future engineers. International Journal of Engineering Pedagogy, 10(3), 106113. https://doi.org/10.3991/ijep.v10i3.12251

[9] Hmad, M., Jan, I., Jabeen, G., \& Alvarado, R. (2021). Does energy-industry investment drive economic performance in regional China: Implications for sustainable development. Sustainable Production and Consumption, 27, 176-192. https://doi.org/10.1016/ j.spc. 2020.10 .033

[10] Hong, X., Cao, X., Gong, Y., \& Chen, W. (2021). Quality information acquisition and disclosure with green manufacturing in a closed-loop supply chain. International Journal of Production Economics, 232. https://doi.org/10.1016/j.ijpe.2020.107997

[11] Jin, J., \& Chen, Y. (2020). Research on the practice of talent cultivation based on the improvement of innovation ability-taking electrical engineering automation technology as an example. Paper presented at the Journal of Physics: Conference Series, 1651(1) https://doi.org/10.1088/1742-6596/1651/1/012007

[12] Laurett, R., Paço, A., \& Mainardes, E. W. (2021). Sustainable development in agriculture and its antecedents, barriers, and consequences - an exploratory study. Sustainable Production and Consumption, 27, 298-311. https://doi.org/10.1016/j.spc.2020.10.032

[13] Li, C., Huang, J., Tian, X., \& Lin, Z. (2021). Demand analysis of new engineering talents and exploration of specialty construction path in application-oriented universities under intelligent information environment. https://doi.org/10.1007/978-3-030-53980-1_133

[14] Lockhart, K., \& Mun, R. U. (2020). Developing a strong Home-School connection to better identify and serve culturally, linguistically, and economically diverse gifted and talented students. Gifted Child Today, 43(4), 231-238. https://doi.org/10.1177/1076217520940743

[15] Mandal, P., Perumal, G., Arora, H. S., Ghosh, S. K., \& Grewal, H. S. (2021). Green manufacturing of nanostructured al-based sustainable self-cleaning metallic surfaces. Journal of Cleaner Production, 278. https://doi.org/10.1016/j.jclepro.2020.123373

[16] Mina, H., Kannan, D., Gholami-Zanjani, S. M., \& Biuki, M. (2021). Transition towards circular supplier selection in petrochemical industry: A hybrid approach to achieve sustainable development goals. Journal of Cleaner Production, 286 https://doi.org/ 10.1016/j.jclepro.2020.125273

[17] Obukhova, L. A., Galustyan, O. V., Baklanov, I. O., Belyaev, R. V., Kolosova, L. A., \& Dubovitskaya, T. V. (2020). Formation of organizational competence of future engineers by means of blended learning. International Journal of Engineering Pedagogy, 10(2), 119-127. https://doi.org/10.3991/ijep.v10i2.12047

[18] Petelin, A. S., Galustyan, O. V., Prosvetova, T. S., Petelina, E. A., \& Ryzhenkov, A. Y. (2019). Application of educational games for formation and development of ICT competence of teachers. International Journal of Emerging Technologies in Learning, 14(15), 193-201. https://doi.org/10.3991/ijet.v14i15.10572 
[19] Ping, L. (2020). Enlightenment of skill competition to training of high-quality applied talents: Taking industrial robot application in e-commerce logistics as an example. Paper presented at the ACM International Conference Proceeding Series, 39-43. https://doi.org/ $\underline{10.1145 / 3407703.3407712}$

[20] Report of the World Commission on Environment and Development: Our Common Future https://sustainabledevelopment.un.org/content/documents/5987our-common-future.pdf

[21] Szromek, A. R., Herman, K., \& Naramski, M. (2021). Sustainable development of industrial heritage tourism - A case study of the industrial monuments route in Poland. Tourism Management, 83. https://doi.org/10.1016/j.tourman.2020.104252

[22] Taheri, P. (2018). Project-based approach in a first-year engineering course to promote project management and sustainability. International Journal of Engineering Pedagogy, 8(3), 104-119. https://doi.org/10.3991/ijep.v8i3.8573

[23] Yin, S., Zhang, N., Li, B., \& Dong, H. (2021). Enhancing the effectiveness of multi-agent cooperation for green manufacturing: Dynamic co-evolution mechanism of a green technology innovation system based on the innovation value chain. Environmental Impact Assessment Review, 86. https://doi.org/10.1016/j.eiar.2020.106475

[24] Wood, R., McGlashan, A., Moon, C., \& Kim, W. Y. (2018). Engineering education in an integrated setting. International Journal of Engineering Pedagogy, 8(3), 17-27. https://doi. org/10.3991/ijep.v8i3.7857

[25] Zaher, A. A., \& Damaj, I. W. (2018). Extending STEM education to engineering programs at the undergraduate college level. International Journal of Engineering Pedagogy, 8(3), 416. https://doi.org/10.3991/ijep.v8i3.8402

[26] Zhang, J., Mao, J., Fan, W., Li, Q., \& Wang, Y. (2020). Practice of training building industrialization talents under the background of new engineering by course reconstruction. Paper presented at the IOP Conference Series: Earth and Environmental Science, 555(1) https://doi.org/10.1088/1755-1315/555/1/012123

\section{Authors}

Vladimir A. Kirik is Director of Academy of Psychology and Pedagogy of Southern Federal University, Rostov-on-Don, Russia.

Shanyi Cheng is Postgraduate, Faculty of Management, Southern Federal University.

Natalia I. Vyunova is Professor of Department of Pedagogy and Pedagogical Psychology of Voronezh State University, Voronezh, Russia.

Olga V. Galustyan is Professor of the Department of Education and Pedagogical Sciences, Academy of Psychology and Pedagogy of Southern Federal University, Rostov-on-Don, Russia.

Saida S. Gamisonija is Postgraduate of the Department of Education and Pedagogical Sciences, Academy of Psychology and Pedagogy of Southern Federal University, Rostov-on-Don, Russia.

Sofia D. Galustyan is Student of the Department of Correctional Pedagogy, Academy of Psychology and Pedagogy of Southern Federal University, Rostov-onDon, Russia.

Article submitted 2021-02-19. Resubmitted 2021-06-13. Final acceptance 2021-06-13. Final version published as submitted by the authors. 